\title{
Politics of Solidarity and Agency in an Age of Precarity
}

\section{Marcel Paret, University of Utah, United States, and University of Johannesburg, South Africa}

\begin{abstract}
This article critically examines Guy Standing's A Precariat Charter by posing three questions: 1) What is the significance of the North/South divide for the global spread of the precariat? 2) Is the precariat an agent of transformation, or simply a passive recipient? 3) How should we understand the fragmentation of the working class and its implications for progressive change? In addressing these questions, I argue that Standing's analysis offers useful insights into the current era of insecurity. But it downplays important variations in forms of precarity, and also over-emphasises fragmentation and weakness. The limits of this approach are illustrated through two empirical examples drawn from Johannesburg, South Africa, and Oakland, United States. Taken together, these examples point towards a broader and more fluid understanding of the "working class". They also underscore possibilities for working-class solidarity, both between stable workers and their more precarious counterparts, and between different groups that Standing identifies as the precariat.
\end{abstract}

\section{KEY WORDS}

working class; protest; unions; Occupy movement; migrant workers; solidarity

Guy Standing's analysis of the "precariat" - as a new global class that is, in his words, "in the making" - is an important intervention with both academic and political implications. It identifies a common trend of market-oriented class restructuring that is spreading across the globe, and links this trend to political changes such as the rise of populism and the declining significance of unions. For these reasons it should be taken very seriously.

To be sure, Standing is not the first or the only person to highlight the growing insecurity of workers across the globe. The notion of precarity is itself at least a few decades old, and there is a substantial and growing literature on labour insecurity in the current global economy (Bieler, Lindberg and Pillay, 2008; Webster, Lambert and Bezuidenhout, 2008; Kalleberg, 2011). Further, as Offe (2011) notes, "there is no shortage of concepts in sociology which seem to target the same or very similar phenomenon of social life as the "precariat", from the "sub-proletariat" and the "working poor" to the "underclass", "marginalised" and "excluded."

Yet Standing $(2011,2014)$ makes especially bold claims about both the current state of global capitalism and the prospects for social change. In terms of the former, he argues that the precariat is expanding rapidly and rather uniformly across the world, and has been doing so since the 1970s. In terms of the latter, he argues that the precariat is a key agent of progressive transformation, and is the group that is most likely to usher in a more just and secure society. 
Standing outlines these arguments in his most recent book, A Precariat Charter: From Denizens to Citizens, which both clarifies the argument of his previous book, The Precariat: The New Dangerous Class, and responds to its critics. The new volume also goes beyond its predecessor by outlining a political platform, which Standing refers to as a Precariat Charter. Consisting of various institutional and policy proposals, the Precariat Charter is designed to inspire and give coherence to a political movement against precarity, or what he refers to as a "Great Transformation towards a Good Society".

This more recent iteration of the precariat argument raises a number of important questions. I propose to take up three questions in particular. First, what is the significance of the North/South divide for the global spread of the precariat? Second, is the precariat an agent of transformation, or simply a passive recipient? Third, how should we understand the fragmentation of the working class and its implications for progressive change? These questions are useful because they illuminate key strengths and weaknesses in Standing's argument, and also because they point towards useful extensions and reconstructions. I address each question in turn, and then put them into context by unpacking two very different examples of collective action from Johannesburg, South Africa, and Oakland, United States. Challenging some of Standing's most pessimistic concerns, these examples underscore possibilities for solidarity within a broadly defined working class, including the traditional "proletariat" and various layers of the so-called "precariat".

\section{Precariat North and South}

The Precariat focused primarily on the advanced economies of the Global North, with particular attention to the United States, United Kingdom, Japan, France, Germany, Spain and South Korea (Standing, 2011). Critics took issue with Standing's neglect of the developing world. They noted that labour has always been precarious in the Global South, and that the vast majority of precarious workers live in the Global South (Breman, 2013; Munck, 2013). Standing does not offer an explicit response to these critiques in A Precariat Charter. Instead he highlights the Great Convergence of capital, wages and living standards between advanced economies and emerging economies. If on the one hand this means the further decline of conditions in the North, on the other hand it means the world is increasingly subject to a uniform process of growing insecurity.

There is some value in this argument. Not only is capital becoming increasingly global, spanning countries, but different national economies are also being restructured in parallel ways. Take, for example, the rise of subcontractors and temporary employment brokers, the privatisation of public services, and the growth of casual employment. Each of these trends cuts across the North/South divide. But the parallels should not be overemphasised, as precarious labour may be situated in very different contexts. As Breman (2013: 137) notes, "there is not one but a variety of regimes of informal/precarious labor, not all vicious to the same extent".

Of primary importance is the greater proportion of surplus labour in the Global South, which is increasingly concentrated in urban areas. This phenomenon is captured vividly by Mike Davis' (2007) portrayal of a Planet of Slums, consisting of peri-urban areas throughout Africa, Asia and Latin America that are defined by underemployment, poverty and "informal" income-generating activity. Much of this surplus labour force fits the following definition provided by Standing:

The precariat consists of people living through insecure jobs interspersed with periods of 
unemployment or labor-force withdrawal (misnamed as 'economic inactivity') and living insecurely, with uncertain access to housing and public resources. They experience a constant sense of transiency (Standing, 2014: 16).

In this sense it may be reasonable to refer to a precariat in the Global South. But it must also be recognised that, compared to more affluent countries, spells of unemployment and labour-force withdrawal are likely to last longer, and reach a greater proportion of the population, in the developing world. These differences are further compounded by important cross-national variations with respect to political and legal institutions, including the structure of trade unions and the broader framework of industrial relations.

To illustrate some of this variation, let us briefly examine the 2011 workforce in two subnational units - the state of California in the United States, and Gauteng province in South Africa. ${ }^{1}$ Both are major economic hubs, but California is significantly more affluent. Whereas the unemployment rate in California was only 12 per cent, in Gauteng it was 30 per cent (including discouraged work-seekers). Accounting for differences in purchasing power parity, 20 per cent of the workforce in California lived on less than the US minimum wage, compared to 45 per cent in Gauteng. These differences underscore the greater depth of precarity in Gauteng. By contrast, however, among employed workers, part-time employment was more than three times as prevalent in California as it was in Gauteng ( 22 per cent vs. 6 per cent), and 84 per cent of California workers were not in unions, compared to 68 per cent in Gauteng. On the flip side, only 32 per cent of workers in California lacked an employer-sponsored medical plan, compared to 62 per cent in Gauteng (Paret, 2016).

This investigation, extremely limited as it is, highlights both the inevitably diverse forms that precarity takes and their unevenness across contexts. The contrast between Los Angeles and Johannesburg is also closely tied to another concept which has proven to be remarkably difficult to pin down: informality. For Standing, the rise of the precariat stems from moves by capital to lower labour costs, increase labour flexibility and maximise profit. This hollowing-out of "formal" labour, which is compounded by declining state protection, may be understood as informalisation from above. These processes have gone hand-in-hand with the deepening penetration of markets across the globe, and thus have impacted the Global North as well as the Global South. Yet the much smaller size of the economy in the South - as measured, for example, by lower income per capita and fewer employment opportunities - means that many people are also forced to create their own employment opportunities. It is this informalisation from below that has led to the popular concept of the "informal economy". Far from being separate processes, informalisation from above and below are often deeply entangled (Valodia and Devey, 2012). Understanding precarity in the Global South requires attending to these linkages.

\section{Agents of Transformation?}

While Standing does take time to clarify his argument regarding who the precariat is and why it is growing, the main goal of $A$ Precariat Charter is to provide a precariat-inspired political platform:

1 This analysis is drawn from Paret (2016). It is based on the 2011 American Community Survey (California) and the 2011 South African Census (Gauteng). 
In short, this book is an attempt to formulate an agenda for the precariat that could be the basis of a political movement, based not on a utilitarian appeal to a majority but on a vision of what constitutes a Good Society (Standing, 2014: viii).

Modelled after weighty documents such as the Magna Carta, the English Bill of Rights, the Chartist Movement declaration, and the United Nations Declaration of Human Rights, this agenda comes in the form of a charter consisting of twenty-nine Articles, each one making specific recommendations for how to alleviate the vulnerabilities of the precariat. Article 25 - the proposal for a universal basic income - is the proposal for which Standing is best known, and one which he has been actively promoting through the Basic Income Earth Network. ${ }^{2}$ It should be recognised, though, that this proposal has a long history, and Standing is only one of its many proponents (Widerquist et al., 2013).

But who exactly is the Charter for? Or as Standing puts it himself: "The big question is: Where is the agency to give it strength?” (Standing, 2014: 150). A Precariat Charter suggests two very different answers. One answer is that the precariat will be the agent of change. Here Standing suggests that the precariat will lead the next Great Transformation, just as the proletariat did in the early twentieth century. Marking a slight deviation from the pessimism of The Precariat, he finds inspiration in the 2011 wave of global protest that included the Arab Spring, the Occupy movement, riots in Britain, and protest movements in Portugal, Spain and Italy. But for him the protests lacked strategy and remained in the "primitive rebel phase" (Standing 2014: 32). Ultimately, therefore, he is concerned that the precariat still do not have "a common consciousness or a common view of what to do about precarity" (Standing, 2014: 31).

Standing thus maintains a mixed viewed of the precariat, which is further exemplified by his labelling of it as a "dangerous class" (Standing, 2014: 31-32). On the positive side, Standing argues that the precariat is dangerous because it carries transformative potential. This potential, he suggests, stems from the fact that its class interests are opposed to both the neo-liberal Right and the social democratic Left. The latter is especially problematic for Standing, because it focuses narrowly on obtaining "full employment" and linking benefits and protections to stable jobs. With little hope of obtaining these privileges, the precariat aspires to a world where economic security is no longer contingent upon "subordinated labour", and where individuals have more control of their own time and productive capacity (Standing 2014: 137, 388).

On the negative side, Standing argues that the precariat is dangerous because it suffers from a combination of anxiety, alienation, anger and anomie, which in turn lead to internal conflict, riots and protests, and to social ills such as drug use, crime and domestic violence (Standing, 2014: 32). While Standing seems to hope that the positive transformative potential will become more prevalent, at least in the present he suggests that the negative effects of insecurity are a more accurate description. It is worth noting that protests fall on the negative side of the equation. Indeed, one may sense that Standing is suspicious of struggles that emerge outside of formal arenas. A primary goal of his Precariat Charter is to construct institutionalised channels whereby the precariat may exercise "Voice" and play a role in policy making (see, for example, Article 5: Promote Associational Freedom).

\footnotetext{
${ }^{2}$ See http://www.basicincome.org/bien/aboutbien.html.
} 
This scepticism regarding precariat-led transformation leads to a second, and alternative, view of agency. In the absence of an organised and coherent precariat movement, Standing seems to suggest that policy makers are the true agents of change. He notes in the Preface:

This book ... is intended to prompt others to focus on policies and institutional changes to reach out to the precariat. Indeed, the energy to write this book stemmed from anger that mainstream policymakers and the media were so bereft of empathy with the precariat and the growing numbers of denizens in their midst (Standing, 2014: viii, original emphasis).

This somewhat paternalistic view stands in stark tension with the notion of the precariat as a transformative agent. But it fits with the project of developing a Precariat Charter. Rather than examining the politics of the precariat - such as through a serious unpacking of the numerous precariat-led uprisings that have been taking place across the globe - Standing chose instead to outline his own vision of how to help the precariat. Reflecting on the situation of the precariat in 2013, he argues that they "were aware of what they were against ... [but] they were not yet agreed on, or perhaps even aware of, what they needed or wanted" (Standing, 2014: 31-32). Standing has thus chosen to substitute for the precariat's lack of awareness and political agency by providing his own political agenda.

The tension between these competing views of the precariat - as a transformative agent that will lead from below, or as a disorganised force that must be saved from above - runs throughout the book. If we want to take the former possibility seriously, though, then we must pay closer attention to precariat struggles - their days of rage, their tent city camps, their fluid forms of organisation, their slogans and social media - and the possibilities that they hold. It may be correct, to a certain extent, to suggest that members of the precariat have yet to settle on a common political agenda. But to suggest that they do not know what they need or want, or to deny their ongoing collective struggles, is incorrect and potentially harmful. Across the globe, people working and living under precarious conditions are building new solidarities and resisting precarity in a variety of ways, even if they are not necessarily doing so in the name of the precariat as such (Paret, 2016). Presuming a pre-defined precariat subject, and imposing goals or political orientations onto that subject, may obfuscate ongoing resistance and possibilities for change.

\section{Fragmentation and Progressive Potential}

Standing's pessimistic view of the current period, and particularly the absence of progressive politics, is closely linked to his analysis of class politics. For him the traditional proletariat, organised into unions, is no longer an agent of transformation. It is primarily interested in reproducing a dying order of stable employment and institutions of social democracy - a political programme he refers to as "labourism". Due to their obsession with the labourist agenda, he argues, the organised working class is becoming increasingly detached from the growing ranks of the precariat, who do not share the same concerns:

Collective agreements that preserve labor security are unlikely to appeal to the precariat. Those in it have little prospect of gaining those securities or the non-wage benefits won by the proletariat and salariat. Some in the precariat do not even seek them. They are unlikely to be 
impressed by union calls for such benefits to be 'extended' to the precariat (Standing, 2014: 136).

Standing does not provide much evidence to back up this claim. If one were to do a proper study of political attitudes among those in precarious employment, one may find that many workers do seek traditional labour securities and the protection that comes with unionisation. Yet there is also likely to be more than a hint of truth in Standing's analysis. As stable employment declines and jobs become more incongruous with traditional union approaches, collective struggles are likely to take new forms. While he is quite sceptical about their relevance, Standing appropriately recognises that the recent wave of global protest marks the emergence of new forms of organisation (Standing, 2014: 133-138).

If Standing believes that unions are essentially irrelevant to the future of progressive class struggle, he is also sceptical about the political possibilities associated with certain fractions of the precariat. Within the precariat he distinguishes between three groups (Standing, 2014: 28-31). The first group includes those who have been bounced from the traditional proletariat, and who wish for a return to a more stable past. This is the least progressive group, as it is prone to populism and demonises other sections of the precariat - such as migrants - for their own plight. The second group includes "traditional denizens" such as migrants, ethnic minorities and ex-convicts who have the least secure rights. Standing suggests that this group tends to avoid politics or, as he puts it, "they keep their heads down" (Standing, 2014: 29). With the first group at war with the second group, and the second group just trying to stay afloat, in Standing's view, neither one is likely to lead the collective charge towards a better future.

Standing's hope for the precariat thus rests on the third group, which includes the young and the educated. Similar to "graduates without a future", whom Paul Mason (2012) celebrates as the spark behind the recent wave of global protest, this group experiences "status frustration" because the available opportunities do not match their skills and aspirations. For Standing, this element is progressive, largely because it rejects the stale labourism of the traditional proletariat:

But because of their education, and awareness of the drabness or absurdity of the labor they are expected to accept, they are well placed to appreciate the delusion of laborism and the need for a new progressive vision (Standing, 2014: 30).

For Standing, this is the group that is most likely to usher in the Great Transformation. It is the vanguard fraction of the vanguard precariat. According to this analysis, the key question is thus whether the educated youth will be able to convince the migrants, ethnic minorities, ex-convicts and those formerly in stable employment to get on board with its progressive vision.

This analysis offers two useful insights. First, it highlights important variations in the forms and experiences of vulnerability. Insecurity is deepening and becoming more widespread, but it is far from uniform. We already highlighted, above, important variations across regions of the global economy. But even within a given national or local context, different groups experience insecurity in very different ways. Second, it poses the question of solidarity. If collective struggles are going to develop further, and if they are going to have any success in transforming social relations, it will certainly require building solidarity across these various divisions.

At the same time, however, Standing's analysis is limited due to its oversimplification and 
focused attempt at identifying the vanguard. His four-piece typology, including the proletariat and the three varieties of the precariat, is somewhat useful for painting broad strokes, but the empirical realities are likely to be more complex. Various groups may blend together at the household level, for example, while specific individuals may move between the categories or belong to multiple categories. More importantly, just as Standing perhaps underestimates the capacity for organised labour to reinvent itself (Voss and Sherman, 2000), he also underestimates the capacity of the precariat. This is especially evident with respect to migrant workers, who in recent decades have led important struggles in places such as the United States and France.

\section{Case Studies of Collective Action}

These limitations underscore the need for empirical examples. Towards this end, the following discussion turns to two case studies of collective action which took place at opposite ends of the globe. The first involves an upsurge of community protests and their changing relationship to unions in Johannesburg. The second involves struggles surrounding May Day in Oakland. These case studies are necessarily limited, given the space available here. But they nonetheless address the aforementioned concerns regarding North/South variation, agency and fragmentation.

As noted above, the character of economic insecurity is dramatically different in Gauteng, South Africa, where Johannesburg is located, and California, United States, where Oakland is located. Whereas unemployment and low income are more prevalent in Gauteng, a greater proportion of the California workforce is foreign-born and non-citizen. A detailed analysis of this divergence and its implications is beyond the scope of this study (for a more thorough comparative examination, see Paret, 2016). But the two examples provide a brief window into two very different instances of collective action.

With regard to the latter two issues, these examples take "agency from below" seriously, even if the investigation is brief, and they pose the question of whether economic insecurity is fuelling fragmentation or solidarity. The examples challenge Standing's characterisation of specific groups. Whereas the Johannesburg example suggests that unionised workers are not necessarily regressive, the Oakland example highlights the agency of migrant workers and the significance of those who are especially marginalised. Finally, while both examples affirm Standing's warnings about diversity and possible fragmentation, they also underscore possibilities for solidarity, thus challenging an analysis that over-determines internal conflict.

\section{The United Front in Johannesburg ${ }^{3}$}

The particularities of precarity in the Global South are evident in Johannesburg, which is located within South Africa's Gauteng province. On the one hand there is evidence of the very same push towards labour flexibility that has spread through much of the Global North. The rise of casualised employment relations and the growing use of labour brokers have eroded labour's core constituency of stable workers, and contributed to declining wages and working conditions (Kenny and Webster, 1998; Webster, 2005). On the other hand, however, this flexible labour force is flanked by a large

\footnotetext{
3 This section draws on twenty-seven months of ethnographic fieldwork conducted in Gauteng metropolitan region - of which Johannesburg lies at the centre - between 2007 and 2015. This research included 283 qualitative interviews with workers and residents of working-class communities.
} 
reserve army of labour, which must eke out a living through occasional temporary jobs, informal activities, small state social grants, and sharing at the household level. While much of the reserve army may seem to fit into Standing's (2014: 13) unelaborated category of the "lumpen-precariat", such a characterisation downplays the extent to which people are both ready and willing to work, and are occasionally employed under extremely precarious conditions. In this context, the reserve army of labour and the precariat are overlapping categories, as many individuals move consistently in and out of work.

Over the past decade, the poverty that is propelled by precarious employment and underemployment has led to an outbreak of community-based protests in townships and informal shack settlements (Alexander, 2010). These increasingly numerous and often quite militant (Paret 2015a) uprisings are popularly referred to as "service delivery" protests. This is because they frequently demand the state provision of services such as water, electricity and refuse removal. But the demands also frequently extend well beyond the traditional realm of services to include resources such as housing or jobs, or to include more general demands for recognition and representation in local government. Community protests are commonly quite loosely organised, prompting Hart (2013) to refer to them as "movements beyond movements".

Community protests are typically propelled by the most marginalised layers of the workforce: the unemployed, the casually employed, and those who rely on informal activities to secure their daily livelihood. One could reasonably argue that they are precariat uprisings. These layers are especially prominent within impoverished townships and informal shack settlements, where community protests are concentrated. This does not, however, mean that more stable workers, including union members, are entirely absent. Survey evidence from 2008 and 2012, for example, suggests that between 25 and 45 per cent of union members within the Congress of South African Trade Unions (COSATU) had participated in a community protest (Paret, 2015b). Evidence also suggests that union members share many of the same grievances that underpin community protests, particularly regarding poor service delivery and government corruption (Paret, 2015c). To the extent that union members have engaged in post-apartheid community struggles, however, they have largely done so as individuals, without union organisational support.

This upsurge of activity within communities has been paralleled by consistent resistance at the workplace. South Africa has one of the highest levels of labour unrest in the world. According to official statistics provided by the South African Department of Labour, between 2005 and 2013 there was an average of 82 strike actions and 5.2 million working days lost per year. This worker-led resistance, however, has been largely detached from the precariat uprisings in the townships (Paret, 2015b, 2015d). To be sure, many unionised workers also face precarious working conditions (Barchiesi, 2011). Stable workers are also frequently called upon to support extended kin networks at the household level. Nonetheless, as Standing would predict, unions have focused primarily on extending their reach into vulnerable sectors, and on protecting those in stable, full-time jobs.

Yet new developments are emerging. In December 2013 the National Union of Metalworkers of South Africa (NUMSA) - the largest trade union in the country - decided to sever ties with the ruling party and establish a United Front that would bring together workplace and community struggles. Such a task is not without challenges, and some of these resonate with Standing's warnings. Some union members, for example, believe that organised workers are the vanguard, and that protesting communities are leaderless and without direction. Such views will be an obstacle to building solidarity between the more stable sections of the working class and their more precariously 
situated counterparts. As the NUMSA-initiated United Front slowly begins to take shape, however, it is already beginning to build bridges across the workplace-community divide, and between the more precarious and more stable layers of the workforce.

The first major outing for the United Front was a one-day "Strike for Youth Jobs" in February 2014. The strike was partially about NUMSA's opposition to legislation - the Employment Tax Incentive Act, or "Youth Wage Subsidy" as it is commonly referred to - which promises to further erode the core of stable labour by providing subsidies to employers who hire young workers. In this sense the march fit nicely with Standing's characterisation of unions as protecting their own narrow interests. But the march was framed much more broadly as being about issues of youth unemployment. In turn, it drew substantial support from community activists and the youth predominantly those without stable employment - who were inspired and emboldened by NUMSA's position. A young man in his 20s, who self-identified as an "unemployed graduate", explained:

I saw that this thing is talking to me directly as an individual. Unemployment is a major issue and it's reached a crisis point, so it's very important that we now come in masses to support these kinds of marches as the youth, to show them we are tired of this unemployment, we are tired of our graduates not finding jobs (Paret, 2014).

This statement, made by a young "graduate without a future" - Standing's vanguard fraction of the precariat - illustrates an appreciation for, and identification with, the union-led movement. But such sentiments were not limited to the youth. A slightly older man, probably in his 40s, from the impoverished and overcrowded Alexandra township, had never been to a protest before. He showed up because he was frustrated with the current state of the economy, and how the government is neglecting the poor. Attracted by the protest's emphasis on employment, he noted: 'I'm a suffering man, because I am not working.... For creating jobs I blame the president always. He doesn't care for us the poor people."

The United Front has also begun to provide support and build solidarity at the community level. This has been especially apparent on the well-known East Rand - a historic manufacturing centre and NUMSA's stronghold, and also a site of recent community protests, where NUMSA locals have given renewed strength to long-standing community struggles around issues of service delivery. As part of these efforts, NUMSA has begun to build local Political Discussion Forums (PDFs), which bring together shop stewards and community activists at the local level. Such efforts have led to union involvement in community protests, as well as to involvement by the unemployed and casually employed in workplace protests. These instances of solidarity across layers of the workforce defined by different levels of insecurity remain intermittent. But they underscore the potential of the United Front for undermining the process of fragmentation.

Not only may the United Front create links between organised workers, unorganised workers and the unemployed, but it has the potential to create bridges between community-based precariat struggles, which up to now have largely remained isolated and distinct from each other. Rather than reifying divisions based on varying levels of economic insecurity, this project hints at the value of rescuing a broad understanding of the "working class" - however heterogeneous it may be - and using it as a basis for building solidarity. At a broader level, the "NUMSA moment", as many are calling it, has re-energised the Left. While certainly not the only such force, organised labour thus 
lies at the centre of progressive politics in South Africa. This challenges Standing's idea that the traditional proletariat is a spent and regressive force.

\section{May Day in Oakland ${ }^{4}$}

May Day 2012 in Oakland, California, highlighted a different set of dynamics which are, to some extent, even more directly related to Standing's analysis of the precariat. Limping along after months of brutal police repression, Occupy Oakland - like many other manifestations of the nationwide Occupy movement - saw May Day as an opportunity to re-establish its tent-city camp. While many commentators have seized on the general assemblies of the Occupy movement - with their hand signals and "open mics" held up as examples of participatory democracy - at least in Oakland, the camp was equally as important, if not more so. Not only did the camp demand attention, but it also created a space where a wide variety of people could come together and experiment with alternative forms of social organisation. As one active participant remarked:

The pulsing heart of the camp was never primarily the General Assembly. It was the kitchen ... we ate together, we listened together, we spoke together, and we were tear gassed together ... that tiny stretch of Oakland was perhaps the least segregated neighborhood in the city, and the only place in the city where I would ever have the conversations I had with the people I did (Brady, 2011).

To be sure, life in the camp was not always as rosy as this suggests. Threats of sexual harassment and other forms of insecurity lingered. But the camp nonetheless underscored one of the most impressive aspects of the Occupy movement in Oakland: solidarity. The camp thrust together people from a wide range of social and economic backgrounds - students and professors, part-time service workers and the unemployed, the homeless and those with stable shelter, young and old, people with little political experience and those with a great deal, and so on. Even if that togetherness was often characterised by discomfort, the tension gave the movement energy, as well as a sense that something larger was at stake.

In a very brief analysis of the Occupy movement, Standing (2014: 133) suggests that the "lumpen-precariat and those with social illnesses" were a dead weight, coming only "in search of soup, sandwiches, medical help and sympathy". It is likely true, as he further argues, that the "drive and energy came from the educated part of the precariat, not the bewildered and atavistic parts" (Standing, 2014: 133). But to imply that the most downtrodden should be expelled from the movement, so that the educated and well-off elements can get on with the decision making, misses a central point of the Occupy camp. The camp was not simply about achieving recognition, as Standing suggests. Indeed, Occupy Oakland often shunned the recognition it received from the local state, consistently refusing to participate in attempts at dialogue. Rather, the camp was as much about experimenting with alternative, non-marketised social relationships, as difficult as such a task may be within the belly of American capitalism. From the perspective of Standing's Polanyian analysis, which links the growth of the precariat to the ascendance and implementation of freemarket ideology, this should be a welcome form of experimentation.

4 This research is based on active and daily participation between October 2011 and May 2012 in both Occupy Oakland and the Dignity and Resistance Coalition.

Global Labour Journal, 2016, 7(2), Page 183 
If the quest for a physical home lay beneath Occupy Oakland's hopes for May Day, a central tension revolved around its relationship to another resistance formation - the Dignity and Resistance Coalition (DRC) - which sought to carry on an annual tradition of protest for migrant communities. In the early 2000s, migrant workers in Los Angeles breathed new life into May Day, establishing it as an annual day of action for migrant workers and migrant rights. In 2006 the May Day tradition spread across the country, serving as the climax of a national wave of uprisings against proposed legislation that would have further criminalised migrants. Seeking to highlight the contributions of migrants to the economy, the 2006 protests featured a nationwide boycott of work, school and business, and were dubbed by some as "A Day Without Immigrants". From 2007 onwards the tradition of May Day marches took hold across California and the rest of the country, and became an institution in both Oakland and neighbouring San Francisco (Paret, 2016).

The stage was thus set for conflict when Occupy movements across the country began to support the call, originating from Los Angeles, for a "general strike" on May Day 2012. Some migrant rights activists understood the call, and especially the reference by Occupy Wall Street in New York City to "A Day Without the 99\%", as either co-opting or erasing the prior years of migrant-led struggle. In Oakland this complicated dynamic compounded a more recent history of racially inflected tensions. The DRC was in fact spearheaded by Decolonize Oakland, a group that broke away from Occupy Oakland due to its "failure to fully address the ways that race, gender, and sexual oppression intersect with capitalism in the lives of Oakland's communities of color" (Decolonize Oakland, 2012). Joining together with long-time migrant activists, Decolonize Oakland and later the DRC began to mobilise for May Day with a greater focus on migrant rights and issues facing people of colour.

The events that unfolded with Occupy Oakland and the DRC offer two lessons regarding the precariat. One lesson is that it is not only the educated youth who have an important role to play in progressive struggles. The DRC, for example, included many older migrant workers who had been active in building migrant rights struggles for many years - including, but not limited to, May Day protests. The coalition also included 200 migrant ex-workers of the Pacific Steel manufacturing plant in Berkeley, California, who had recently been fired due to their undocumented legal status. This group eventually led the May Day march under a banner that read "Dignity and Resistance". These various migrant activists, and more generally their legacy of struggle, challenge Standing's assertion that migrants within the precariat simply keep their heads down, and tend to avoid engaging in collective struggles.

A second lesson is that relations within the precariat are more complex than Standing's narrative, which emphasises internal conflict, suggests. While there were certainly tensions, there were also important moments of solidarity. A key tension revolved around the issue of legal permits. While migrant activists were adamant that marching without a legal permit would put undocumented people at risk, Occupy activists had long refused to recognise the authority of the local state. The Occupy activists worried that the legal DRC march would create a harmful divide between "good"/legal protesters and "bad"/illegal protesters, and in turn undermine their attempt to illegally occupy the park. The tension reached a boiling point at a joint meeting when one Occupy activist explained, "We have tried really hard to be illegal." This was, of course, a slap in the face to the migrant activists, for whom battling illegality is a primary line of defence. They left the meeting feeling disregarded and excluded from the "movement of the 99 percent".

But the precariat was not always at war with itself. Activists from the Occupy Oakland Labor 
Solidarity Committee (OOLS) - which included both an older generation of socialists with significant organised labour experience, and a younger contingent that fits fairly closely with Standing's notion of the educated vanguard - played an important bridging role. OOLS activists, for example, had met with members of the Pacific Steel Workers' organising committee several months earlier to discuss the firings of undocumented migrant workers. This meeting led to the joint organisation of a successful protest against the firings on February 17. Billed as a March for Dignity, the flyers called for supporters to "Defend the Human and Labor Rights of All Workers" (original emphasis). Laying the foundation for the May Day action, this protest was led by the Pacific Steel Workers, but also included a substantial contingent of Occupy activists - including many who were not participants in OOLS - as well as migrant rights activists from around the San Francisco Bay Area. Rather than reactionary anti-immigrant hostility, this was a strong showing of solidarity.

Both solidarity and division were evident on May Day. Occupy Oakland had its own events downtown in the morning, which led to standoffs with police. As things settled down in the early afternoon, the police-escorted DRC march left the predominantly Latino Fruitvale neighbourhood without a hitch. Only a small group of Occupy activists were present for the start of the march, but a much larger contingent met the march at the midway point, which was halfway between Fruitvale and the plaza in the middle of downtown. The plaza was both the end point of the march, and the site of the previous, and possibly future, Occupy camp. The two groups continued the march together, reaching the plaza in greater numbers than they began. The DRC then led a relatively calm rally, which featured activists from both groups. But the police presence grew as the sun went down, and there was no significant attempt to re-Occupy the plaza.

In the end, then, there was a very clear division between "good"/legal protesters (the DRC) and "bad"/illegal protesters (Occupy Oakland) on May Day. While this tension never went away, it did not prevent the two different groups from "finding" each other and marching together. The convergence illustrated the possible seeds of a united movement against precarity, bridging the gaps between educated youth, long time labour activists, migrant workers and countless others. At least for a brief moment, solidarity triumphed over fragmentation.

\section{Solidarity and the Working Class}

These two scenarios offer a different vantage point than the one provided by Standing's analysis of the precariat. His analysis emphasises divisions and vanguard elements, which in turn leads him to undermine important struggles by various groups such as unionised and migrant workers. In contrast, the events surrounding the United Front in Johannesburg and May Day in Oakland pose the question of solidarity: To what extent are collective actors with different vulnerabilities and resources able to forge common struggles? Both scenarios underscore the difficulties associated with building solidarity in an era of heightened insecurity. But they also suggest that such solidarity is far from impossible.

This approach is consistent with a broader and more fluid understanding of the "working class". At a structural level, we may follow Michael Denning and

insist that 'proletarian' is not a synonym for 'wage laborer' but for dispossession, expropriation and radical dependence on the market. You don't need a job to be a proletarian: wageless life, not wage labor, is the starting point in understanding the free market (Denning, 2010: 81). 
This understanding of the proletariat, or working class, may include stable and unionised workers, as well as those who are precariously employed, informally employed or unemployed. These different positions may be associated with very different lived experiences and political orientations, which are also shaped by various other factors such as gender, race, neighbourhood, legal status and national context.

Standing is absolutely correct to emphasise varying levels and forms of insecurity. But his analysis may over-determine the political significance of this variation by asserting a strong divide between the "proletariat" and "precariat", as well as seemingly impenetrable divisions within the latter. To the extent that individuals who are encompassed within Denning's definition do, in fact, develop collective perspectives, goals and struggles, the outcomes are far from determined. Their politics may be varied and divergent, and may even lead to conflict, as Standing suggests. Or they may converge, as I have sought to illustrate through the examples above from Johannesburg and Oakland. These solidarities, however momentary, underscore the relevance of maintaining the idea, or aspiration, of the working class as a broadly constituted political agent.

The "working class" may therefore come to be defined broadly or narrowly, depending on how struggles unfold. Standing's most optimistic vision rests on a narrowly defined "proletariat" that excludes those outside of stable, unionised employment. But as the Johannesburg example presented above suggests, the working class may also be extended to include more marginalised groups, such as unemployed township dwellers. Standing's most optimistic vision also entails the formation of a unified precariat. But collective struggles against insecurity may not necessarily be organised around the mantle of precarity as such. As in California, for example, they may be organised around expanding rights for undocumented migrant workers. While the diversity of antiprecarity struggles may be weakened by their fragmentation, such differences do not necessarily imply conflict. Even if not directly related, diverse struggles may inspire each other, and potentially even lead to a domino effect of positive changes that extends beyond the immediate context. Extending legal residence rights to undocumented workers, for example, may end up strengthening various groups of native-born workers by making it more difficult for employers to exploit one of the most vulnerable segments of the workforce.

To be sure, greater solidarity is likely to lead to greater possibilities for transformation. In this sense Standing is onto something important by underscoring the question of solidarity among those groups that are especially insecure. But we must not assume who will lead and participate in progressive struggles, or how the participants will identify themselves and define their demands. A more critical, and even more optimistic, position is to remain open to the different possible forms that solidarity and struggle may take.

\section{REFERENCES}

Alexander, Peter (2010) Rebellion of the Poor: South Africa's Service Delivery Protests - A Preliminary Analysis. Review of African Political Economy, 37: 25-40.

Barchiesi, Franco (2011) Precarious Liberation: Workers, the State, and Contested Citizenship. Albany: State University of New York Press.

Bieler, Andreas, Ingemar Lindberg and Devan Pillay (2008) Labor and the Challenges of Globalization: 
What Prospects for Transnational Solidarity? Pietermaritzburg: University of KwaZulu-Natal Press.

Brady, Aaron (2011) The Oakland Commune. Available online at http://www.possiblefutures.org/2011/12/05/oakland-commune/ (accessed 23 January 2013).

Breman, Jan (2013) A Bogus Concept. New Left Review, 84: 130-138.

Davis, Mike (2007) Planet of Slums. London: Verso.

Decolonize Oakland (2012) Communiqué from Decolonize Oakland. Available online at https://occupyoakland.org/2012/03/communique-from-decolonize-oakland-3-18-12/ (accessed 21 March 2012).

Denning, Michael (2010) Wageless Life. New Left Review, 66: 79-97.

Hart, Gillian (2013) Rethinking the South African Crisis: Nationalism, Populism, Hegemony. Athens: University of Georgia Press.

Kalleberg, Arne (2011) Good Jobs, Bad Jobs: The Rise of Polarized and Precarious Employment Systems in the United States, 1970s to 2000s. New York: Russell Sage.

Kenny, Bridget and Edward Webster (1998) Eroding the Core: Flexibility and the Re-Segmentation of the South African Labor Market. Critical Sociology, 24: 216-243.

Mason, Paul (2012) Why It's Kicking Off Everywhere: The New Global Revolutions. London: Verso.

Munck, Ronaldo (2013) The Precariat: A View from the South. Third World Quarterly, 34(5): 747-762.

Offe, Claus (2011) The Vanishing "Shadow of the Future" European Journal of Sociology, 52(3): 466474.

Paret, Marcel (2014) NUMSA Strike and the United Front. South African Labour Bulletin, 38 (May/June): 23-26.

Paret, Marcel (2015a) Violence and Democracy in South Africa's Community Protests. Review of African Political Economy, 42(143): 107-123.

Paret, Marcel (2015b) Labor and Community Struggles, 1994-2014. In New South African Review 5: Beyond Marikana, edited by Gilbert M. Khadiagala, Prishani Naidoo, Devan Pillay and Roger Southall. Johannesburg: Wits University Press.

Paret, Marcel (2015c) COSATU and Community Struggles: Assessing the Prospects for Solidarity. In COS ATU in Crisis: The Fragmentation of an African Trade Union Federation, edited by Vishwas Satgar and Roger Southall. Sandton: KMM Review.

Paret, Marcel (2015d) Precarious Labor Politics: Unions and the Struggles of the Insecure Working Class in the United States and South Africa. Critical Sociology, 41(4-5): 757-784.

Paret, Marcel (2016) Precarious Class Formations in the United States and South Africa. International Labor and Working Class History, 68: 84-106.

Standing, Guy (2011) The Precariat: The New Dangerous Class. London: Bloomsbury Academic.

Standing, Guy (2014) A Precariat Charter: From Denizens to Citizens. London: Bloomsbury Academic.

Valodia, Imraan and Richard Devey (2012) The Informal Economy in South Africa: Debates, Issues and Policy. Margin - the Journal of Applied Economic Research, 6(2): 133-157.

Voss, Kim and Rachel Sherman (2000) Breaking the Iron Law of Oligarchy: Union Revitalization in the American Labor Movement. American Journal of Sociology, 106(2): 303-349. 
Webster, Edward (2005) Making a Living, Earning a Living: Work and Employment in Southern Africa. International Political Science Review, 26: 55-71.

Webster, Edward, Rob Lambert and Andries Bezuidenhout (2008) Grounding Globalization: Labor in the Age of Insecurity. Malden, MS: Blackwell.

Widerquist, Karl, José A. Noguera, Yannick Vanderborght and Jurgen de Wispelaere (2013) Basic Income: An Anthology of Contemporary Research. Chichester: John Wiley \& Sons.

\section{BIOGRAPHICAL NOTE}

MARCEL PARET is an Assistant Professor in the Department of Sociology at the University of Utah, and Senior Research Associate with the South African Research Chair in Social Change at the University of Johannesburg. He holds a PhD in Sociology from the University of CaliforniaBerkeley. [Email: marcelparet@gmail.com] 